\title{
WACLAW KOZAKIEWICZ
}

\section{IN MEMORIAM}

One of the important manifestations of Canadian growth in the last decades has been the development of the older universities and the foundation of new ones, but it is perhaps little realized how much this development has depended upon the immigration of scholars educated in other countries. One of these foreign scholars, who in a few years exerted an influence at the Dominion Bureau of Statistics and in three of our universities, was Waclaw Kozakiewicz whose death on March 8, 1959 at the age of fortyeight deprived Canadian mathematics of an outstanding scholar and teacher.

Kozakiewicz was a student at Warsaw in the period between the two wars which Professor Zygmund described in his lecture at the Second Canadian Mathematical Congress at Vancouver in 1949. He attended, among others, the lectures of Nikodym and Sierpinski, but his doctoral thes is was written under the direction of Mazurkiewicz. He joined the Polish armed forces in France at the outbreak of war and served until the collapse of France in June, 1940. Unable to leave France, he taught Mathematics at the Polish Lyceum for the following four years. Ordered to report for compulsory labour in Germany, he escaped into Spain and, aided by the American Polish Relief Council, eventually reached Canada in October, 1944. Some two months later he joined the staff of the Dominion Bureau of Statistics in Ottawa. "His extraordinary competence in mathematics", Dr. Nathan Keyfitz writes, "and in the application of mathematics to statistics was of great use at a time when major sample surveys were under development. Besides taking part in the detailed activities associated with these he spent much of his own time in giving instruction to Dominion Bureau of Statistics personnel on topics in pure and applied mathematics. Though he stayed only until August 1, 1945, his contribution was important, and officials of the Bureau are proud of having been associated with him in the early days of his Canadian career". But his true métier was teaching and in the autumn of 1945 he accepted an offer to go as associate professor to the University of Saskatchewan where he remained for four years. There he took a very active part in the mathematical seminars held at the University and accustomed himself to Canadian life.

In 1949 the University of Montreal wishing to initiate the study of mathematical statistics and wishing to add to their staff a mathematician trained in the French tradition, invited 
Kozakiewicz to become a member of their staff. He impressed the students not only by the clarity of his teaching but also by his friendliness and the amount of time he was willing to give to students outside of the classroom. He supervised a few theses in statistical theory and the present ambitious programme in statistics at the University of Montreal is built upon the foundations which he laid there.

In 1951 he migrated to McGill University where he supervised the theses of students working for the master's degree and the doctor's degree in Real Variable Theory, Probability Theory and Statistics. His ability and great knowledge of these subjects always aroused the respect and admiration of his students. Those who attended the seminar of the Canadian Mathematical Congress in Halifax in 1951 will recall that he was one of those who gave instructional courses.

At Saskatchewan his closest friend was W.J.R. Crosby who writes - "One thing that must have immediately struck those who met Kozakiewicz was his courtesy - a characteristic that was the result both of his training and of his natural consideration of others. He was brought up in an environment where politeness was perhaps valued a little more highly and expected more regularly than it is in many other places. He loved his native country, Poland, and quietly and unobtrusively was proud of and loyal to the customs and virtues which he considered characteristic of the best of his people. He was unpretentious, but he respected his obligations in every sphere of life and kept them before him. He was thoughtful and careful, but not diffident, serious but also light-hearted".

While at the Dominion Bureau of Statistics, Kozakiewicz met Miss Naomi Pelletier, who became Mrs. Kozakiewicz in the winter of 1947. She and their son John survive him.

$$
\text { W.L.G.W. }
$$

\section{BIBLIOGRAPHY}

1. Sur un théorème sur les opérateurs et son application a la théorie des laplaciens généralisés, Comptes rendus Soc. Scientif. Varsovie 26, (1933), 18-24.

2. Sur les fonctions caractéristiques et leur application aux théorèmes limites du calcul des probabilités; Annales de la Société Polonaise Mathem. 13 (1935), 24-43.

3. Sur un théorème de Glivenko - C.R. Soc. Scientif. Varsovie, 1937. 
4. Sur les conditions nécessaires et suffisantes de la convergence stochastique, Comptes rendues de l'Académie des Sciences Paris 205 (1937), 1928-1929.

5. Sur les conditions nécessaires et suffisantes de la convergence stochastique - Fundamenta Matematicae, 1938.

6. Sur un théorème asymptotique du calcul des probabilités, Bulletins de la Soc. Pol. Math. 1938.

7. Sur la convergence forte, Bulletin de l'Académie des Sciences, Paris, 1940.

8. On the necessary and sufficient conditions for the convergence of a sequence of moment generating functions, Annals of Mathematical Statistics 22 (1951), 478-479.

9. On the convergence of moment generating functions, Annals of Mathematical Statistics 18 (1947), 61-69.

10. On the Riemann derivatives of integrable functions, Paul Butzer and W. Kozakiewicz, Canadian Journal of Mathematics 6 (1954), 572-81.

11. Notes on Statistics. Mimeographed and published by McGill University. 